\title{
Frequency, magnitude and character of hyperthermal events at the onset of the Early Eocene Climatic Optimum
}

\author{
V. Lauretano ${ }^{1}$, K. Littler ${ }^{2, a}$, M. Polling ${ }^{1}$, J. C. Zachos ${ }^{2}$, and L. J. Lourens ${ }^{1}$ \\ ${ }^{1}$ Department of Earth Sciences, Faculty of Geosciences, Utrecht University, Heidelberglaan 2, 3584 CS, \\ Utrecht, the Netherlands \\ ${ }^{2}$ Department of Earth and Planetary Sciences, University of California Santa Cruz, 1156 High Street, \\ Santa Cruz, CA 95064, USA \\ ${ }^{a}$ now at: Camborne School of Mines, University of Exeter, Penryn Campus, Penryn, Cornwall, TR10 9FE, UK \\ Correspondence to: V. Lauretano (v.lauretano@uu.nl)
}

Received: 20 April 2015 - Published in Clim. Past Discuss.: 13 May 2015

Revised: 17 September 2015 - Accepted: 19 September 2015 - Published: 7 October 2015

\begin{abstract}
Recent studies have shown that the Early Eocene Climatic Optimum (EECO) was preceded by a series of short-lived global warming events, known as hyperthermals. Here we present high-resolution benthic stable carbon and oxygen isotope records from ODP Sites 1262 and 1263 (Walvis Ridge, SE Atlantic) between $\sim 54$ and $\sim 52$ million years ago, tightly constraining the character, timing, and magnitude of six prominent hyperthermal events. These events, which include Eocene Thermal Maximum (ETM) 2 and 3, are studied in relation to orbital forcing and long-term trends. Our findings reveal an almost linear relationship between $\delta^{13} \mathrm{C}$ and $\delta^{18} \mathrm{O}$ for all these hyperthermals, indicating that the eccentricity-paced covariance between deep-sea temperature changes and extreme perturbations in the exogenic carbon pool persisted during these events towards the onset of the EECO, in accordance with previous observations for the Paleocene Eocene Thermal Maximum (PETM) and ETM2. The covariance of $\delta^{13} \mathrm{C}$ and $\delta^{18} \mathrm{O}$ during $\mathrm{H} 2$ and I2, which are the second pulses of the "paired" hyperthermal events ETM2-H2 and I1-I2, deviates with respect to the other events. We hypothesize that this could relate to a relatively higher contribution of an isotopically heavier source of carbon, such as peat or permafrost, and/or to climate feedbacks/local changes in circulation. Finally, the $\delta^{18} \mathrm{O}$ records of the two sites show a systematic offset with on average $0.2 \%$ heavier values for the shallower Site 1263 , which we link to a slightly heavier isotopic composition of the intermediate water mass reaching the northeastern flank of the
\end{abstract}

Walvis Ridge compared to that of the deeper northwestern water mass at Site 1262.

\section{Introduction}

The early Paleogene was characterized by a highly dynamic climatic system both on long $\left(>10^{6}\right.$ years) and short $\left(<10^{4}\right.$ years) timescales. From the late Paleocene $(\sim 58 \mathrm{Ma})$ to the early Eocene $(\sim 50 \mathrm{Ma})$, Earth's surface experienced a long-term warming trend that culminated in an extended period of extreme warmth, called the Early Eocene Climatic Optimum (EECO; Zachos et al., 2001a, 2008; Bijl et al., 2009; Westerhold and Röhl, 2009). During the EECO, global temperatures reached a long-term maximum lasting about $2 \mathrm{Myr}$, characterized by the warmest temperatures of the Cenozoic (Zachos et al., 2008). Superimposed on the long-term warming trend were a series of short-lived global warming (hyperthermal) events, accompanied by the release of ${ }^{13} \mathrm{C}$-depleted carbon into the ocean-atmosphere carbon reservoirs (Zachos et al., 2005; Lourens et al., 2005; Nicolo et al., 2007; Littler et al., 2014; Kirtland Turner et al., 2014). These events are of particular interest as they represent useful analogs for the current global warming, despite differences in background climatic conditions and rates of change (e.g., Zachos et al., 2008; Hönisch et al., 2012; Zeebe and Zachos, 2013).

The Paleocene Eocene Thermal Maximum (PETM or ETM1, 56 Ma), lasting less than $200 \mathrm{kyr}$, was the most extreme of these episodes. During the PETM global temper- 
ature rose by $5-8^{\circ} \mathrm{C}$, and massive amounts of carbon were released as evidenced by a significant negative carbon isotope excursion (CIE) of $>3 \%$ in the ocean/atmosphere carbon pools, and widespread dissolution of seafloor carbonate (Kennett and Stott, 1991; Dickens et al., 1995; Thomas and Shackleton, 1996; Zachos et al., 2005, 2008; Sluijs et al., 2007; McInerney and Wing, 2011). A series of similar events are recorded in carbonate records from marine and continental deposits from the early Paleogene, as expressed by negative excursions in $\delta^{13} \mathrm{C}$ and $\delta^{18} \mathrm{O}$ often accompanied by dissolution horizons (e.g., Cramer et al., 2003; Lourens et al., 2005; Agnini et al., 2009; Galeotti et al., 2010; Stap et al., 2010; Zachos et al., 2010; Abels et al., 2012, 2015; Slotnick et al., 2012; Kirtland Turner et al., 2014; Littler et al., 2014). Orbitally tuned records for this geological interval provide evidence that the early Eocene hyperthermal events were paced by variations in the Earth's orbit, specifically in the long- and short- eccentricity cycles. (e.g., Cramer et al., 2003; Lourens et al., 2005; Littler et al., 2014; Zachos et al., 2010; Sexton et al., 2011).

Several different carbon sources have been proposed to explain the negative CIE, including (1) the release of methane by thermal dissociation of gas hydrates on the continental slopes (Dickens et al., 1995); (2) the burning of peat and coal deposits (Kurtz et al., 2003); and (3) the release of carbon from thawing of permafrost soils at high latitudes as a feedback or as a direct response to orbital forcing (DeConto et al., 2012); while (4) a redistribution of ${ }^{13} \mathrm{C}$-depleted carbon within oceans has been proposed as a mechanism for hyperthermals in the early to middle Eocene interval (Sexton et al., 2011).

Despite the uncertainty in carbon source and triggering mechanism of the hyperthermal events, a common reservoir has been theorized to explain the consistent covariance in benthic foraminiferal $\delta^{13} \mathrm{C}$ and $\delta^{18} \mathrm{O}$ across both the PETM and ETM2, indicating that changes in the exogenic carbon pool were similarly related to warming during these events (Stap et al., 2010). The aim of this paper is to test this relationship by constraining the relative timing and magnitude of changes in deep ocean temperatures and carbon isotope excursions for a series of carbon isotope excursions that succeed ETM2, initially identified by Cramer et al. (2003) in the composite bulk carbonate $\delta^{13} \mathrm{C}$ record from several deep-sea sites (ODP Sites 690 and 1051; DSDP Site 550 and 577). For this purpose, we generated high-resolution carbon and oxygen stable isotope records of the benthic foraminiferal species Nuttalides truempyi from ODP Sites 1262 and 1263 (Walvis Ridge), encompassing the interval from the ETM2 (Stap et al., 2010) to the ETM3 (Röhl et al., 2005), providing the first complete high-resolution benthic stable isotope records for the early Eocene events leading to the onset of the EECO.

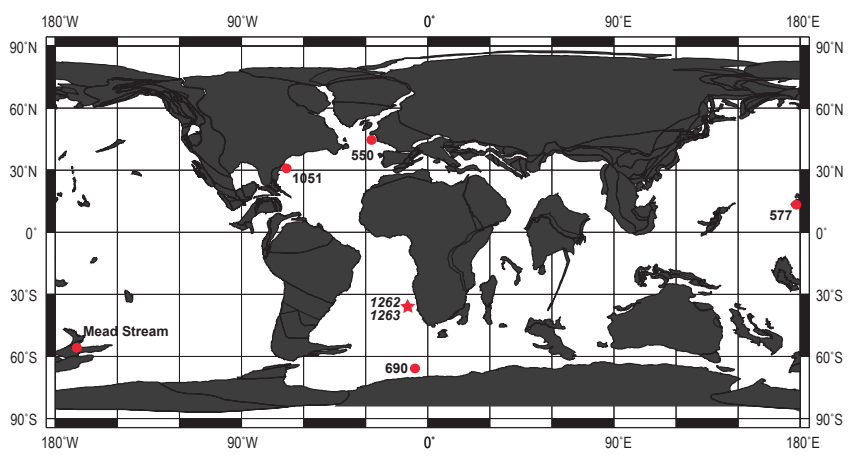

Figure 1. Paleogeographic reconstruction for the early Eocene ( $\sim 54 \mathrm{Ma}$ ) showing the position of Sites 1263 and 1262 (Walvis Ridge), (map provided by Ocean Drilling Stratigraphic Network, ODSN; http://www.odsn.de/odsn/services/paleomap/paleomap. html, modified). Also shown the locations of ODP Sites 690 and 1051 and DSDP Sites 550 and 577 (Cramer et al., 2003) and Mead Stream (Slotnick et al., 2012).

\section{Materials and methods}

\subsection{Site location and sampling}

ODP Sites 1262 and 1263 represent the deepest and shallowest end-members of a $2 \mathrm{~km}$ depth transect recovered during ODP Leg 208. Site 1263 is located just below the crest of the northeast flank of Walvis Ridge, in the southeastern Atlantic, at a water depth of $2717 \mathrm{~m}$, whereas Site 1262 was drilled near the base of the northwestern flank of Walvis Ridge at a water depth of $4759 \mathrm{~m}$ (Fig. 1). The estimated paleodepths of Sites 1262 and 1263 at $\sim 56 \mathrm{Ma}$ were $\sim 3600$ and $1500 \mathrm{~m}$, respectively (Zachos et al., 2004). The material recovered at the two sites provided an expanded sequence of early Paleogene sediments, yielding a complete section mainly composed of calcareous nannofossil ooze, chalk and marls. The composite depth scale for Site 1263 was constructed using the magnetic susceptibility (MS) and sediment lightness $\left(\mathrm{L}^{*}\right)$ from the four holes (Zachos et al., 2004).

Samples were collected at the Bremen Core Repository from Holes A, B and C for Site 1263, and Holes A and B for Site 1262, according to the shipboard meters composite depth section (mcd; Zachos et al., 2004). A $28 \mathrm{~m}$ thick interval of Site 1263 was sampled at a resolution of $5 \mathrm{~cm}$ from $\sim 268$ to $\sim 296 \mathrm{mcd}$, and a $\sim 6 \mathrm{~m}$ interval of Site 1262 was sampled at a resolution of $3 \mathrm{~cm}$ from $\sim 103$ to $\sim 109 \mathrm{mcd}$ (Fig. 3). Prior to the analyses, samples were freeze dried, washed and sieved to obtain fractions larger than 38, 63 and $150 \mu \mathrm{m}$ at the University of California, Santa Cruz and Utrecht University.

\subsection{Stable isotopes}

Multi-specimen samples of $N$. truempyi were picked from the $>150 \mu \mathrm{m}$ fraction. The stable isotope values of picked specimens (average of 6-8 foraminiferal calcite tests) from Site 
1263 were carried out at Utrecht University using a CARBOKIEL automated carbonate preparation device linked on-line to a Thermo-Finnigan MAT253 mass spectrometer. Calibrations to the international standard (NBS-19) and to the inhouse standard (Naxos marble) show an analytical precision of 0.03 and $0.08 \%$ o for $\delta^{13} \mathrm{C}$ and $\delta^{18} \mathrm{O}$, respectively. The stable isotope values of picked specimens from Site 1262 were analyzed on a KIEL IV carbonate preparation device linked on-line to a Thermo-Finnigan MAT253 mass spectrometer, at the UCSC Stable Isotope Laboratory, Santa Cruz. Calibrations to the in-house standard Carrara marble (CM05) and international standards (NBS-18 and NBS-19) yield an analytical precision of 0.05 and $0.08 \%$, for $\delta^{13} \mathrm{C}$ and $\delta^{18} \mathrm{O}$, respectively. All values are reported in standard delta notation relative to VPDB (Vienna Pee Dee Belemnite). Outliers were defined by adding or subtracting an upper and lower boundary of $2 \sigma$ from a 13-points moving average, following the method by Liebrand et al. (2011). Published benthic isotope data of the same foraminiferal species were included in this study to obtain longer continuous records of Site 1263 and 1262 (Stap et al., 2010; Littler et al., 2014; Figs. 3 and 4).

\subsection{Paleotemperature reconstructions}

Paleotemperatures were obtained from the benthic foraminiferal $\delta^{18} \mathrm{O}$ values by applying the equation of Bemis et al. (1998):

$$
\begin{aligned}
& T\left({ }^{\circ} \mathrm{C}\right)=16.9-4.38\left(\delta^{18} \mathrm{O}_{\mathrm{c}}-\delta^{18} \mathrm{O}_{\mathrm{sw}}\right) \\
& +0.10\left(\delta^{18} \mathrm{O}_{\mathrm{c}}-\delta^{18} \mathrm{O}_{\mathrm{sw}}\right)^{2} .
\end{aligned}
$$

The temperature scale is computed assuming an ice-free sea water value $\left(\delta^{18} \mathrm{O}_{\mathrm{sw}}\right)$ of $-1.2 \%$ (VPDB). This value is calculated correcting the estimated deep-sea $\delta^{18} \mathrm{O}_{\mathrm{sw}}$ value of $-0.98 \%$ (SMOW) relative to PDB scales by subtracting $0.27 \%$ (Hut, 1987). The N. truempyi $\delta^{18} \mathrm{O}$ was adjusted for disequilibrium vital effects by adding $0.35 \%$ (Shackleton et al., 1984; Shackleton and Hall, 1997), on the assumption that the isotopic disequilibrium for this species remained constant through time.

\section{Age model}

Given the typical low-resolution age control afforded by magneto- and bio-stratigraphy, and the availability of a robust cycle (i.e., orbital) based chronology for the Leg 208 sites (Westerhold et al., 2007), we developed an eccentricitytuned age model for the studied interval using the red over green color ratio $\left(\mathrm{a}^{*}\right)$ records of ODP Sites 1263 and 1262 (Fig. 2). For tuning, we applied first spectral analysis in the depth domain using standard Blackman-Tukey and Gaussian filtering techniques as provided by the AnalySeries program (Paillard et al., 1996). Site 1262, the deepest site at Walvis
Table 1. Age-depth tie points based on the tuning of the filtered $3 \mathrm{~m}$ period extracted from the color reflectance record of Site 1262 and the long-eccentricity cycle extracted from the astronomical solution La2010d (Laskar et al., 2011).

\begin{tabular}{lrr}
\hline Site 1262 & $\begin{array}{r}\text { Long-eccentricity cycle (kyr) } \\
\text { Laskar 2010d } \\
\text { (Option 1) }\end{array}$ & $\begin{array}{r}\text { Long-eccentricity cycle (kyr) } \\
\text { Laskar 2010d } \\
(\text { Option 2) }\end{array}$ \\
\hline 102.750 & 51800 & 52206 \\
104.231 & 52003 & 52410 \\
105.711 & 52206 & 52614 \\
107.167 & 52410 & 52816 \\
108.648 & 52614 & 53017 \\
110.129 & 52816 & 53216 \\
111.635 & 53017 & 53415 \\
113.193 & 53216 & 53615 \\
114.750 & 53415 & 53815 \\
116.359 & 53615 & 54016 \\
117.865 & 53815 & 54218 \\
\hline
\end{tabular}

Ridge, was chosen as the backbone for our tuning. The $a^{*}$ record of this site clearly revealed a $\sim 3 \mathrm{~m}$ period, interpreted as reflecting the climatic imprint of the $405 \mathrm{kyr}$ eccentricity cycle (Lourens et al., 2005). Subsequently, we filtered this component and tuned it directly to the extracted $405 \mathrm{kyr}$ eccentricity component of the La2010d orbital solution (Laskar et al., 2011) with maximum a* values, interpreted to represent maximum carbonate dissolution, corresponding to maximum eccentricity values (Table 1). A similar approach was carried out for the $\mathrm{a}^{*}$ record of Site 1263 to evaluate the continuity of the successions and robustness of the filtered output (Fig. 2). Finally, the tuned age model of Site 1262 was transferred to Site 1263 by correlating $>50$ characteristic features in the $\mathrm{a}^{*}$ records of both sites as tie points (Fig. 2 and Table 2).

Different tuning options have been debated in the last 10 years, resulting in an age for the PETM ranging between $\sim 55.5$ and $\sim 56.3 \mathrm{Ma}$ (Lourens et al., 2005; Westerhold et al., 2008; Hilgen et al., 2010; Dinarès-Turell et al., 2014). Here we report on two tuning options (Fig. 2), assigning an age of $53.69 \pm 0.02 \mathrm{Ma}$ (option 1) or of $54.09 \pm 0.02 \mathrm{Ma}$ (option 2) to ETM2 (Westerhold et al., 2007). According to both options, ETM2 predates the 405 kyr maximum falling at an increasing limb, in agreement with observations of Westerhold et al. (2007), but in contrast with the earlier interpretation by Lourens et al. (2005), who aligned this event to a maximum in the $405 \mathrm{kyr}$ cycle. Recent literature revising the Paleocene cyclostratigraphic interpretation (DinarèsTurell et al., 2014; Hilgen et al., 2015) has shown that the Paleocene holds 25, rather than 24, $405 \mathrm{kyr}$ eccentricity cycles. In addition, new $\mathrm{U} \mathrm{Pb}^{-1}$ ages have become available which support an age of $\sim 66.0 \mathrm{Ma}$ for the $\mathrm{K} \mathrm{Pg}^{-1}$ boundary (Kuiper et al., 2008; Renne et al., 2013). These developments point to an age of $\sim 54.0 \mathrm{Ma}$ for ETM2 and therefore we plot our results anchoring the age of ETM2 to option 2 (Fig. 4). Evolutionary wavelet spectra were obtained in the time domain using the wavelet script of Torrence and Compo (http: //paos.colorado.edu/research/wavelets). Prior to the analysis, 

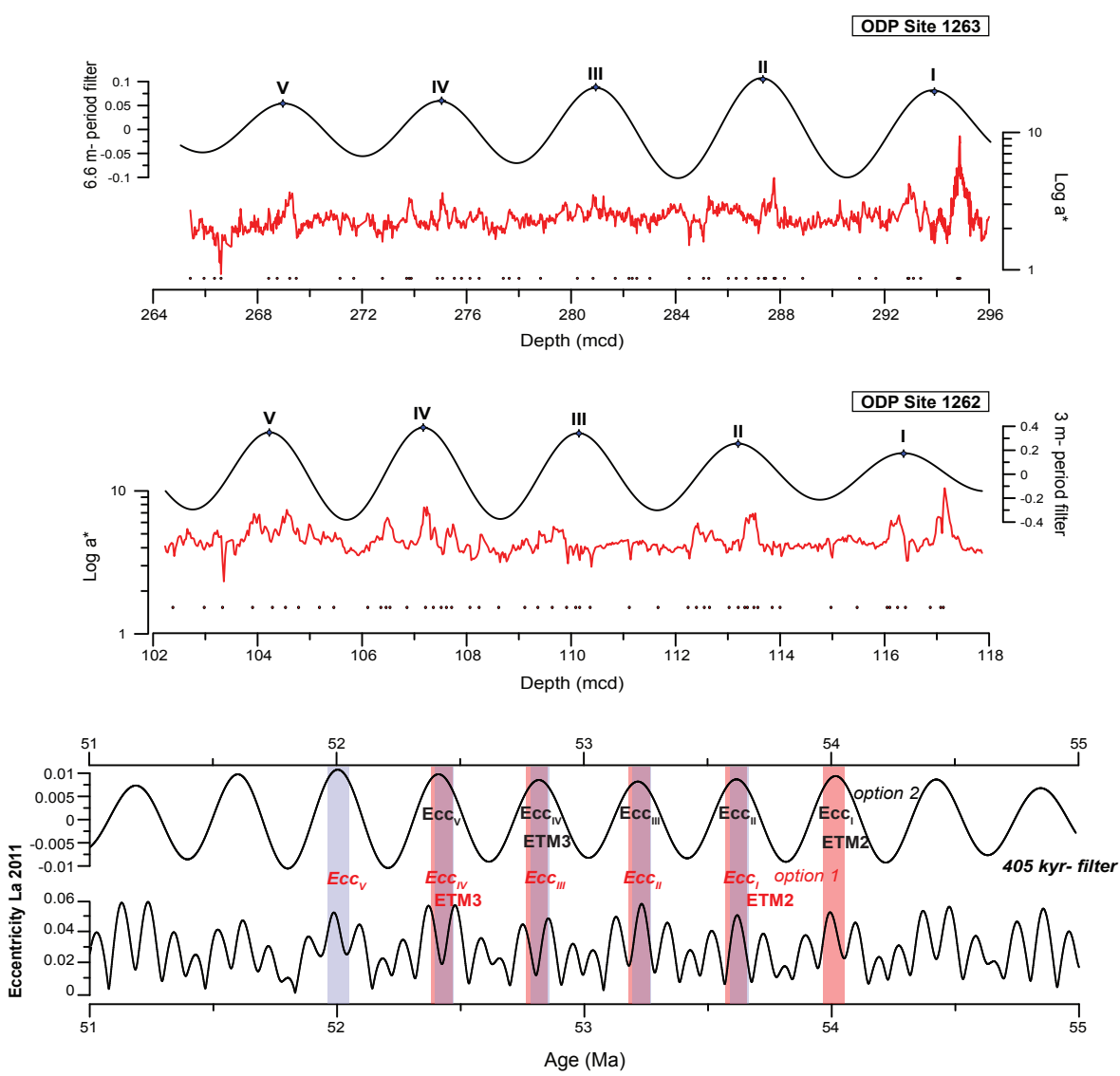

Figure 2. Floating orbitally tuned age model constructed using the red over green color ratio (a*) record of ODP Sites 1262 (red line) and transferred to Site 1263 by using age-depth tie points between the sites (black dots, see Table 2). Two different tuning options are shown based on the ages proposed for the PETM by Westerhold et al. (2008).

carbon and oxygen records were resampled at $2.5 \mathrm{kyr}$, detrended and normalized.

\section{Results}

Our new benthic $\delta^{13} \mathrm{C}$ and $\delta^{18} \mathrm{O}$ records show six major negative excursions between 54 and $52 \mathrm{Ma}$ (Fig. 4). They correspond to the ETM2, H2, I1, I2, J, and ETM3 (or X/K) events, formerly recognized in deep-sea $\delta^{13} \mathrm{C}$ bulk carbonate records and land-based marine and continental sections (Abels et al., 2012, 2015; Agnini et al., 2009; Cramer et al., 2003; Kirtland Turner et al., 2014; Littler et al., 2014; Lourens et al., 2005; Slotnick et al., 2012).

The general long-term trend in our $\sim 2 \mathrm{Myr}$ long records indicates a minor increase between 54.2 Ma and 53.2 Ma followed by an average decrease of $\sim 0.3 \%$ in absolute baseline values of both $\delta^{13} \mathrm{C}$ and $\delta^{18} \mathrm{O}$ following $\mathrm{J}(\sim 53.1 \mathrm{Ma})$, accompanied by minor cycles between the six main events in both records. Following J, both records maintain rather stable values up to ETM3 (Fig. 4). These changes are negligible compared to the Paleocene-Eocene long-term warming trend and long-term negative trend in carbon isotope values. How- ever, the onset of more generally negative $\delta^{13} \mathrm{C}$ values, coinciding with $\mathrm{J}$, has also been observed in the deep-sea bulk carbonate record at Site 1262 (Zachos et al., 2010) and in the land-based section at Mead Stream by Slotnick et al. (2012), who suggested that the pronounced change in lithology beginning with $\mathrm{J}$ could be used as a chronostratigraphic marker for the onset of the EECO.

Evidence for the onset of warmer temperatures leading to the EECO is evident at $\sim 53 \mathrm{Ma}$ in the benthic $\delta^{18} \mathrm{O}$ records at both Sites 1262 and 1263 (Fig. 4). Baseline average $\delta^{18} \mathrm{O}$ values prior to ETM2, signifying the response of the unperturbed oceanic system, indicate a mean deep-sea temperature of $\sim 12{ }^{\circ} \mathrm{C}$, which post-J increases by $>0.5^{\circ} \mathrm{C}$. Despite variability, our data show that this increase in background temperature continued upwards across ETM3. Here we suggest that the onset of the EECO can be identified in our records with the onset of the general low in benthic isotope values initiated with $\mathrm{J}(\sim 53 \mathrm{Ma})$ and thus including ETM3 within the EECO. Although longer high-resolution benthic $\delta^{18} \mathrm{O}$ records are needed to establish the total duration of the EECO, this could represent a first step towards a formal defi- 
Table 2. Tie points between ODP Site 1263 and Site 1262 based on color reflectance records and interpolated ages obtained from the astronomically tuned age model.

\begin{tabular}{|c|c|c|c|c|c|c|c|}
\hline Samples & $\begin{array}{r}\text { Site } 1263 \\
\text { Depth (mbsf) }\end{array}$ & $\begin{array}{r}\text { Site } 1263 \\
\text { Depth (mcd) }\end{array}$ & Samples & $\begin{array}{r}\text { Site } 1262 \\
\text { Depth (mbsf) }\end{array}$ & $\begin{array}{r}\text { Site } 1262 \\
\text { Depth (mcd) }\end{array}$ & $\begin{array}{r}\text { Interpolated Age (Ma) } \\
\text { Option } 1\end{array}$ & $\begin{array}{r}\text { Interpolated Age (Ma) } \\
\text { Option } 2\end{array}$ \\
\hline $1263 \mathrm{~A}-26 \mathrm{H}-4,147.5$ & 228.575 & 265.425 & 1262B-11H-4, 137.5 & 92.275 & 101.855 & 51.610 & 52.014 \\
\hline $1263 \mathrm{~A}-26 \mathrm{H}-5,50$ & 229.1 & 265.95 & $1262 \mathrm{~B}-11 \mathrm{H}-5,42.5$ & 92.825 & 102.405 & 51.727 & 52.132 \\
\hline $1263 \mathrm{~A}-26 \mathrm{H}-5,90$ & 229.5 & 266.35 & 1262B-11H-5, 102.5 & 93.425 & 103.005 & 51.835 & 52.241 \\
\hline $1263 \mathrm{~A}-26 \mathrm{H}-5,115$ & 229.75 & 266.6 & 1262B-11H-5, 137.5 & 93.775 & 103.355 & 51.883 & 52.289 \\
\hline $1263 \mathrm{~A}-26 \mathrm{H}-6,147.5$ & 231.575 & 268.425 & $1262 \mathrm{~B}-11 \mathrm{H}-6,45$ & 94.35 & 103.93 & 51.962 & 52.369 \\
\hline $1263 \mathrm{~A}-26 \mathrm{H}-7,30$ & 231.9 & 268.75 & $1262 \mathrm{~A}-10 \mathrm{H}-2,120$ & 88.2 & 104.31 & 52.014 & 52.421 \\
\hline $1263 \mathrm{~B}-22 \mathrm{H}-5,100$ & 230.9 & 269.23 & $1262 \mathrm{~A}-10 \mathrm{H}-2,145$ & 88.45 & 104.56 & 52.048 & 52.455 \\
\hline $1263 \mathrm{~B}-22 \mathrm{H}-5,125$ & 231.15 & 269.48 & $1262 \mathrm{~A}-10 \mathrm{H}-3,20$ & 88.7 & 104.81 & 52.082 & 52.490 \\
\hline $1263 \mathrm{~B}-22 \mathrm{H}-6,142.5$ & 232.825 & 271.155 & $1262 \mathrm{~A}-10 \mathrm{H}-3,60$ & 89.1 & 105.21 & 52.137 & 52.545 \\
\hline 1263B-22H-7, 45 & 233.35 & 271.68 & $1262 \mathrm{~A}-10 \mathrm{H}-3,87.5$ & 89.375 & 105.485 & 52.175 & 52.583 \\
\hline $1263 \mathrm{~A}-27 \mathrm{H}-1,65$ & 232.75 & 272.78 & $1262 \mathrm{~A}-10 \mathrm{H}-4,2.5$ & 90.025 & 106.135 & 52.265 & 52.673 \\
\hline $1263 \mathrm{~A}-27 \mathrm{H}-2,7.5$ & 233.675 & 273.705 & $1262 \mathrm{~A}-10 \mathrm{H}-4,27.5$ & 90.275 & 106.385 & 52.300 & 52.707 \\
\hline $1263 \mathrm{~A}-27 \mathrm{H}-2,17.5$ & 233.775 & 273.805 & $1262 \mathrm{~A}-10 \mathrm{H}-4,37.5$ & 90.375 & 106.485 & 52.314 & 52.721 \\
\hline $1263 \mathrm{~A}-27 \mathrm{H}-2,25$ & 233.85 & 273.88 & $1262 \mathrm{~A}-10 \mathrm{H}-4,45$ & 90.45 & 106.56 & 52.325 & 52.732 \\
\hline $1263 \mathrm{~A}-27 \mathrm{H}-2,125$ & 234.85 & 274.88 & $1262 \mathrm{~A}-10 \mathrm{H}-4,77.5$ & 90.775 & 106.885 & 52.370 & 52.777 \\
\hline $1263 \mathrm{~A}-27 \mathrm{H}-2,145$ & 235.05 & 275.08 & $1262 \mathrm{~B}-12 \mathrm{H}-1,70$ & 96.6 & 107.24 & 52.420 & 52.826 \\
\hline $1263 \mathrm{~A}-27 \mathrm{H}-3,40$ & 235.5 & 275.53 & $1262 \mathrm{~B}-12 \mathrm{H}-1,85$ & 96.75 & 107.39 & 52.441 & 52.846 \\
\hline $1263 \mathrm{~A}-27 \mathrm{H}-3,67.5$ & 235.775 & 275.805 & $1262 \mathrm{~B}-12 \mathrm{H}-1,100$ & 96.9 & 107.54 & 52.461 & 52.867 \\
\hline $1263 \mathrm{~A}-27 \mathrm{H}-3,100$ & 236.1 & 276.13 & 1262B-12H-1, 110 & 97 & 107.64 & 52.475 & 52.880 \\
\hline $1263 \mathrm{~A}-27 \mathrm{H}-3,135$ & 236.45 & 276.48 & $1262 \mathrm{~B}-12 \mathrm{H}-1,120$ & 97.1 & 107.74 & 52.489 & 52.894 \\
\hline $1263 \mathrm{~A}-27 \mathrm{H}-4,77.5$ & 237.375 & 277.405 & $1262 \mathrm{~B}-12 \mathrm{H}-2,5$ & 97.45 & 108.09 & 52.537 & 52.941 \\
\hline $1263 \mathrm{~A}-27 \mathrm{H}-4,100$ & 237.6 & 277.63 & $1262 \mathrm{~B}-12 \mathrm{H}-2,22.5$ & 97.625 & 108.265 & 52.561 & 52.965 \\
\hline $1263 \mathrm{~A}-27 \mathrm{H}-4,137.5$ & 237.975 & 278.005 & $1262 \mathrm{~B}-12 \mathrm{H}-2,60$ & 98 & 108.64 & 52.613 & 53.016 \\
\hline $1263 \mathrm{~A}-27 \mathrm{H}-5,70$ & 238.8 & 278.83 & $1262 \mathrm{~B}-12 \mathrm{H}-2,110$ & 98.5 & 109.14 & 52.681 & 53.083 \\
\hline $1263 \mathrm{C}-9 \mathrm{H}-4,105$ & 240.45 & 280.24 & $1262 \mathrm{~B}-12 \mathrm{H}-2,135$ & 98.75 & 109.39 & 52.715 & 53.117 \\
\hline $1263 \mathrm{C}-9 \mathrm{H}-5,15$ & 241.05 & 280.84 & $1262 \mathrm{~B}-12 \mathrm{H}-3,12.5$ & 99.025 & 109.665 & 52.753 & 53.154 \\
\hline $1263 \mathrm{C}-9 \mathrm{H}-5,100$ & 241.9 & 281.69 & $1262 \mathrm{~B}-12 \mathrm{H}-3,40$ & 99.3 & 109.94 & 52.790 & 53.191 \\
\hline $1263 \mathrm{C}-9 \mathrm{H}-6,2.5$ & 242.425 & 282.215 & $1262 \mathrm{~B}-12 \mathrm{H}-3,57.5$ & 99.475 & 110.115 & 52.814 & 53.214 \\
\hline $1263 \mathrm{C}-9 \mathrm{H}-6,15$ & 242.55 & 282.34 & $1262 \mathrm{~B}-12 \mathrm{H}-3,65$ & 99.55 & 110.19 & 52.824 & 53.224 \\
\hline $1263 \mathrm{C}-9 \mathrm{H}-6,32.5$ & 242.725 & 282.515 & $1262 \mathrm{~B}-12 \mathrm{H}-3,85$ & 99.75 & 110.39 & 52.851 & 53.251 \\
\hline $1263 \mathrm{C}-9 \mathrm{H}-6,82.5$ & 243.225 & 283.015 & $1262 \mathrm{~B}-12 \mathrm{H}-4,10$ & 100.5 & 111.14 & 52.951 & 53.350 \\
\hline $1263 \mathrm{~A}-28 \mathrm{H}-1,40$ & 242 & 284.52 & $1262 \mathrm{~B}-12 \mathrm{H}-4,65$ & 101.05 & 111.69 & 53.024 & 53.422 \\
\hline $1263 \mathrm{~A}-28 \mathrm{H}-1,95$ & 242.55 & 285.07 & 1262B-12H-4, 122.5 & 101.625 & 112.265 & 53.097 & 53.496 \\
\hline $1263 \mathrm{~A}-28 \mathrm{H}-1,115$ & 242.75 & 285.27 & $1262 \mathrm{~A}-11 \mathrm{H}-1,137.5$ & 96.375 & 112.425 & 53.118 & 53.516 \\
\hline $1263 \mathrm{~A}-28 \mathrm{H}-2,40$ & 243.5 & 286.02 & $1262 \mathrm{~A}-11 \mathrm{H}-2,2.5$ & 96.525 & 112.575 & 53.137 & 53.536 \\
\hline $1263 \mathrm{~A}-28 \mathrm{H}-2,70$ & 243.8 & 286.32 & $1262 \mathrm{~A}-11 \mathrm{H}-2,12.5$ & 96.625 & 112.675 & 53.150 & 53.549 \\
\hline $1263 \mathrm{~A}-28 \mathrm{H}-2,107.5$ & 244.175 & 286.695 & $1262 \mathrm{~A}-11 \mathrm{H}-2,50$ & 97 & 113.05 & 53.198 & 53.597 \\
\hline $1263 \mathrm{~A}-28 \mathrm{H}-3,5$ & 244.65 & 287.17 & $1262 \mathrm{~A}-11 \mathrm{H}-2,67.5$ & 97.175 & 113.225 & 53.220 & 53.619 \\
\hline $1263 \mathrm{~A}-28 \mathrm{H}-3,27.5$ & 244.875 & 287.395 & $1262 \mathrm{~A}-11 \mathrm{H}-2,80$ & 97.3 & 113.35 & 53.236 & 53.635 \\
\hline $1263 \mathrm{~A}-28 \mathrm{H}-3,32.5$ & 244.925 & 287.445 & $1262 \mathrm{~A}-11 \mathrm{H}-2,85$ & 97.35 & 113.4 & 53.243 & 53.642 \\
\hline $1263 \mathrm{~A}-28 \mathrm{H}-3,65$ & 245.25 & 287.77 & $1262 \mathrm{~A}-11 \mathrm{H}-2,97.5$ & 97.475 & 113.525 & 53.258 & 53.658 \\
\hline $1263 \mathrm{~A}-28 \mathrm{H}-3,70$ & 245.3 & 287.82 & $1262 \mathrm{~A}-11 \mathrm{H}-2,105$ & 97.55 & 113.6 & 53.268 & 53.667 \\
\hline $1263 \mathrm{~B}-24 \mathrm{H}-2,147.5$ & 245.875 & 288.165 & $1262 \mathrm{~A}-11 \mathrm{H}-2,132.5$ & 97.825 & 113.875 & 53.303 & 53.703 \\
\hline $1263 \mathrm{~B}-24 \mathrm{H}-3,67.5$ & 246.575 & 288.865 & $1262 \mathrm{~A}-11 \mathrm{H}-2,147.5$ & 97.975 & 114.025 & 53.322 & 53.722 \\
\hline $1263 \mathrm{~B}-24 \mathrm{H}-4,135$ & 248.75 & 291.04 & $1262 \mathrm{~A}-11 \mathrm{H}-3,95$ & 98.95 & 115 & 53.446 & 53.846 \\
\hline 1263B-24H-5, 47.5 & 249.375 & 291.665 & $1262 \mathrm{~A}-11 \mathrm{H}-3,145$ & 99.45 & 115.5 & 53.508 & 53.909 \\
\hline 1263B-24H-6, 20 & 250.6 & 292.89 & $1262 \mathrm{~A}-11 \mathrm{H}-4,52.5$ & 100.025 & 116.075 & 53.580 & 53.981 \\
\hline $1263 \mathrm{C}-10 \mathrm{H}-5,65$ & 251.05 & 292.93 & $1262 \mathrm{~A}-11 \mathrm{H}-4,57.5$ & 100.075 & 116.125 & 53.586 & 53.987 \\
\hline $1263 \mathrm{C}-10 \mathrm{H}-5,82.5$ & 251.225 & 293.105 & $1262 \mathrm{~A}-11 \mathrm{H}-4,72.5$ & 100.225 & 116.275 & 53.605 & 54.006 \\
\hline $1263 \mathrm{C}-10 \mathrm{H}-5,110$ & 251.5 & 293.38 & $1262 \mathrm{~A}-11 \mathrm{H}-4,87.5$ & 100.375 & 116.425 & 53.624 & 54.025 \\
\hline $1263 \mathrm{C}-10 \mathrm{H}-7,1$ & 252.91 & 294.79 & $1262 \mathrm{~A}-11 \mathrm{H}-4,135$ & 100.85 & 116.9 & 53.687 & 54.089 \\
\hline $1263 \mathrm{C}-10 \mathrm{H}-7,5$ & 252.95 & 294.83 & $1262 \mathrm{~A}-11 \mathrm{H}-5,5$ & 101.05 & 117.1 & 53.713 & 54.089 \\
\hline $1263 \mathrm{C}-10 \mathrm{H}-7,10$ & 253 & 294.88 & $1262 \mathrm{~A}-11 \mathrm{H}-5,10$ & 101.1 & 117.15 & 53.720 & 54.122 \\
\hline
\end{tabular}

nition of the warmest interval of the Cenozoic, avoiding ambiguity caused by changes in the timescale.

On the short-term scale, our new data across the events following ETM2 and $\mathrm{H} 2$ indicate a rise in temperature of $\sim 2{ }^{\circ} \mathrm{C}$ and $\sim 1.5^{\circ} \mathrm{C}$ during $\mathrm{I} 1$ and $\mathrm{I} 2$, respectively. The $\mathrm{J}$ event was associated with a temperature increase of $>1{ }^{\circ} \mathrm{C}$ superimposed on the further average decrease in baseline $\delta^{18} \mathrm{O}$ value. ETM3 is expressed in both the shallowest and deepest site at Walvis Ridge by similar isotopic excursions, with a CIE of $\sim 0.8 \%$ and a negative shift in the $\delta^{18} \mathrm{O}$ record of $\sim 0.5 \%$ o, corresponding to a warming in the deep ocean of $2-2.5^{\circ} \mathrm{C}$, comparable to values observed during the ETM2 (Stap et al., 2010).

Evolutionary wavelet analyses for $\delta^{13} \mathrm{C}$ and $\delta^{18} \mathrm{O}$ records of Site 1263 show spectral power concentrated at distinct frequencies, corresponding to the long $405 \mathrm{kyr}$ and short $\sim 100 \mathrm{kyr}$ eccentricity cycles (Fig. 5). The isotope records reveal coherent patterns, with the highest spectral power con- 


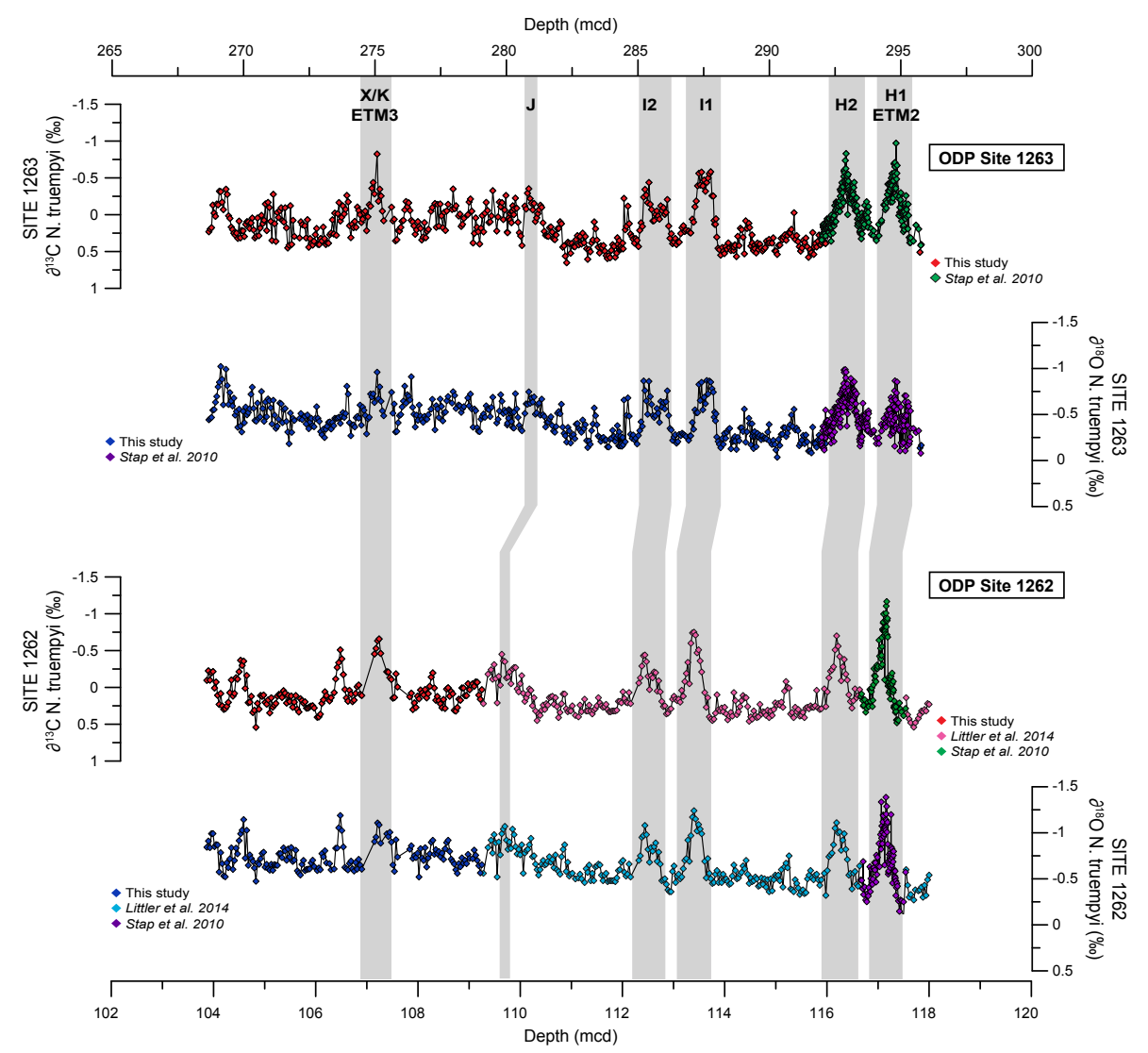

Figure 3. Benthic N. truempyi $\delta^{13} \mathrm{C}$ and $\delta^{18} \mathrm{O}$ records from Site 1263 and Site 1262, plotted versus depth. Highlighted intervals represent the position of the early Eocene hyperthermal events.

centrated during ETM2-H2 and I1-I2. The $\sim 100 \mathrm{kyr}$ signal in $\delta^{13} \mathrm{C}$, which is very prominent in the first $1 \mathrm{Myr}$ of the record, weakens after J. The imprint of precession and/or obliquity forcing is very weak/absent throughout the entire record. As a result of our tuning approach, minima in $\delta^{13} \mathrm{C}$ are approximately in phase with maxima in the $405 \mathrm{kyr}$ and $\sim 100$ kyr eccentricity cycles, following previous work (e.g., Cramer et al., 2003; Lourens et al., 2005; Zachos et al., 2010; Stap et al., 2010).

\section{Discussion}

\subsection{Isotope covariance}

Our high-resolution benthic isotope records provide a direct constraint on the relationship between the temperaturerelated signal carried by the benthic foraminiferal $\delta^{18} \mathrm{O}$ and the CIEs during the events leading to the EECO. The six events recognized in the benthic records vary in terms of both magnitude of the CIEs and inferred temperature changes. The most intense perturbations are associated with ETM2, $\mathrm{I} 1$ and ETM3, whereas $\mathrm{H} 2$ and $\mathrm{I} 2$, which lag the larger events by one $100 \mathrm{kyr}$ eccentricity cycle, are less prominent (Fig. 4). One important question then is whether all these events of varying magnitude are accompanied by the same source of light carbon released into the ocean atmosphere system and climatic response. Following Stap et al. (2010), we have assessed this by comparing the slopes of the regression lines between the carbon and oxygen isotopes of the individual events (Fig. 6). These cross-plots clearly show that all events exhibit significant and coherent linear correlation at both sites with slopes ranging between 0.5 and 0.7 (Fig. 6), indicating a consistent relationship for all events between changes in deep-sea temperatures and carbon release. We conclude that this significant covariance between benthic $\delta^{13} \mathrm{C}$ and $\delta^{18} \mathrm{O}$ records suggests a strong non-linear response to orbital forcing of global temperatures and the release of isotopically light carbon (e.g. methane gas and/or $\mathrm{CO}_{2}$ ) into the ocean-atmosphere system during eccentricity maxima, driving subsequent carbonate dissolution and enhanced greenhouse warming, as has been observed in the older part of the record at Site 1262 (Stap et al., 2010; Littler et al., 2014). This conclusion is further underlined by the consistent scaling of CIE magnitudes between our deep-sea data and soil nodule records of the Bighorn basin for these events, which strengthens the hypothesis of a similar isotopic 


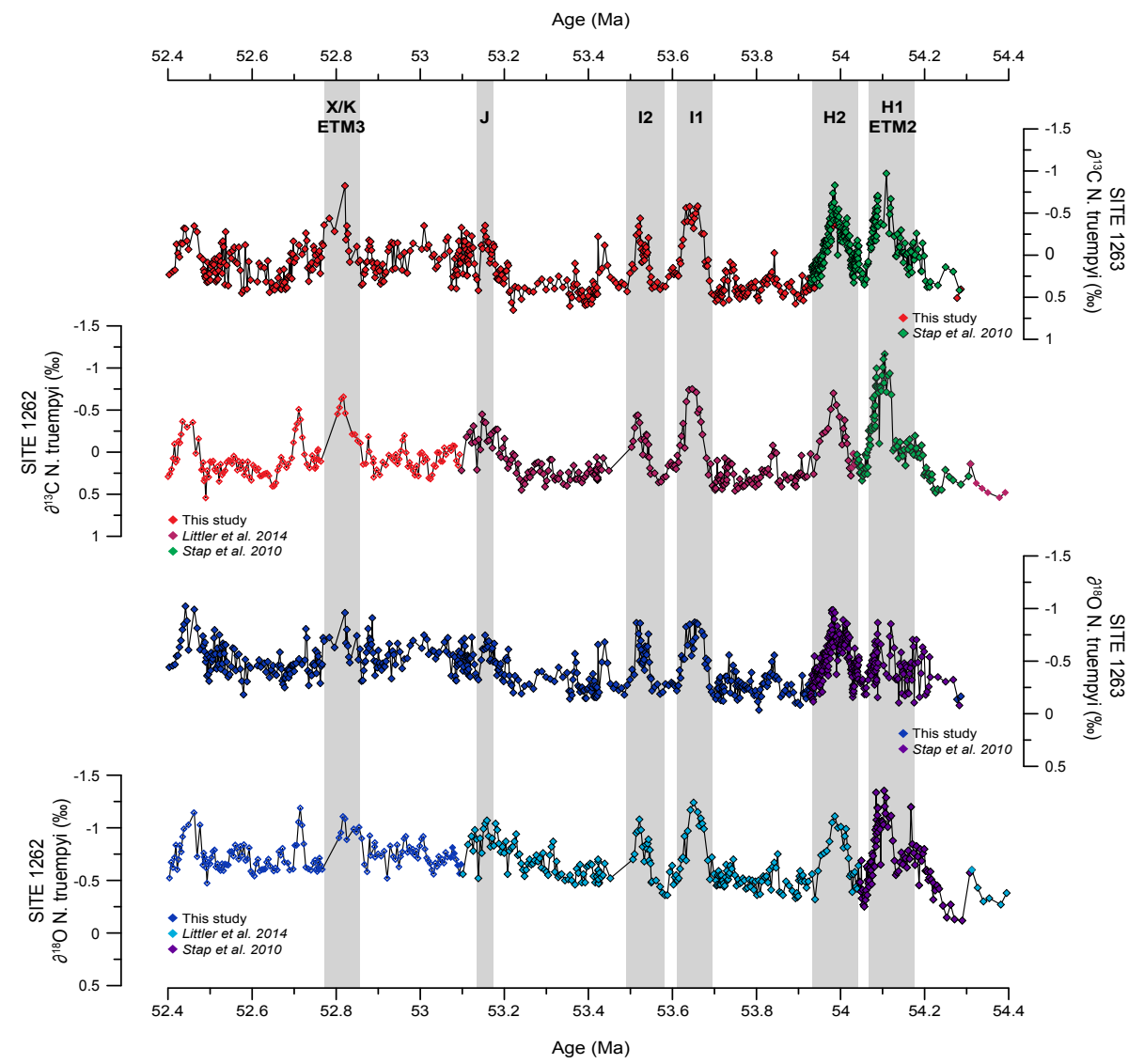

Figure 4. Benthic N. truempyi $\delta^{13} \mathrm{C}$ and $\delta^{18} \mathrm{O}$ records from Site 1263 and Site 1262, plotted versus Age (Ma), (starting from option 2 for the age of ETM2 by Westerhold et al., 2008). Highlighted intervals represent the position of the early Eocene hyperthermal events.

composition of the carbon source for the early Eocene hyperthermal events (Abels et al., 2015).

\subsection{The "paired" hyperthermal events}

The slopes of the regression lines for $\mathrm{H} 2$ and $\mathrm{I} 2$ appear slightly steeper than those of ETM2, I1, J and ETM3 (Fig. 6). To statistically test this (dis)similarity, we applied a Student t-test to pairs of slopes, comparing all the events against each other using both a pooled and an unpooled error variance. The results show that the null hypothesis (the slopes being similar, $\alpha=0.05$ ) is satisfied in the case of ETM2, I1, J and ETM3. The tests on the steeper slopes of $\mathrm{H} 2$ and $\mathrm{I} 2$ generally display values of $p \leq 0.05$ when tested against the other events, but values of $p \geq 0.05$ when tested against each other. This implies that the smaller events, $\mathrm{H} 2$ and $\mathrm{I} 2$, are statistically similar to each other but differ slightly from the other perturbations. Even though this statistical approach might be subject to limitations derived from the range of data points chosen for each event, it clearly shows that the slopes for $\mathrm{H} 2$ and I2 deviate from the average values given by the other events. Moreover, the statistical deviation of the slopes of $\mathrm{H} 2$ and $\mathrm{I} 2$ is clearer when comparing them with the aver- age slope calculated for all the events at each site, since the slopes of H2 and I2 fall outside the (99.99\%) confidence limits (Fig. 7). The average slope between $\delta^{13} \mathrm{C}$ and $\delta^{18} \mathrm{O}$ of 0.6 for both sites is also in accord with previous observations for the onset/recovery of PETM, ETM2 and H2 by Stap et al. (2010).

The "paired" hyperthermal events, ETM2-H2 and I1-I2 thus reveal slightly different $\delta^{13} \mathrm{C}$ vs. $\delta^{18} \mathrm{O}$ relationships between their first (ETM2 and I1) and secondary (H2 and I2) pulses. Assuming that these signals are globally representative, this could imply that the second of the two pulses had a relatively larger contribution of an isotopically heavier carbon source than the first pulse. Such a mechanism could hint to a methane-related dominant carbon source (e.g. methane hydrates) during the initial phase of the paired hyperthermal events that is mostly depleted, so that other relatively heavier carbon isotope sources (e.g. wetlands, peat) become progressively more important during the successive event. Warming of intermediate water during ETM2 and I1, as previously suggested for the PETM and ETM2 (Jennions et al., 2015; Lunt et al., 2010), could have destabilized methane clathrates leading to their dissociation and the subsequent increased warming and large CIE. Mechanisms re- 


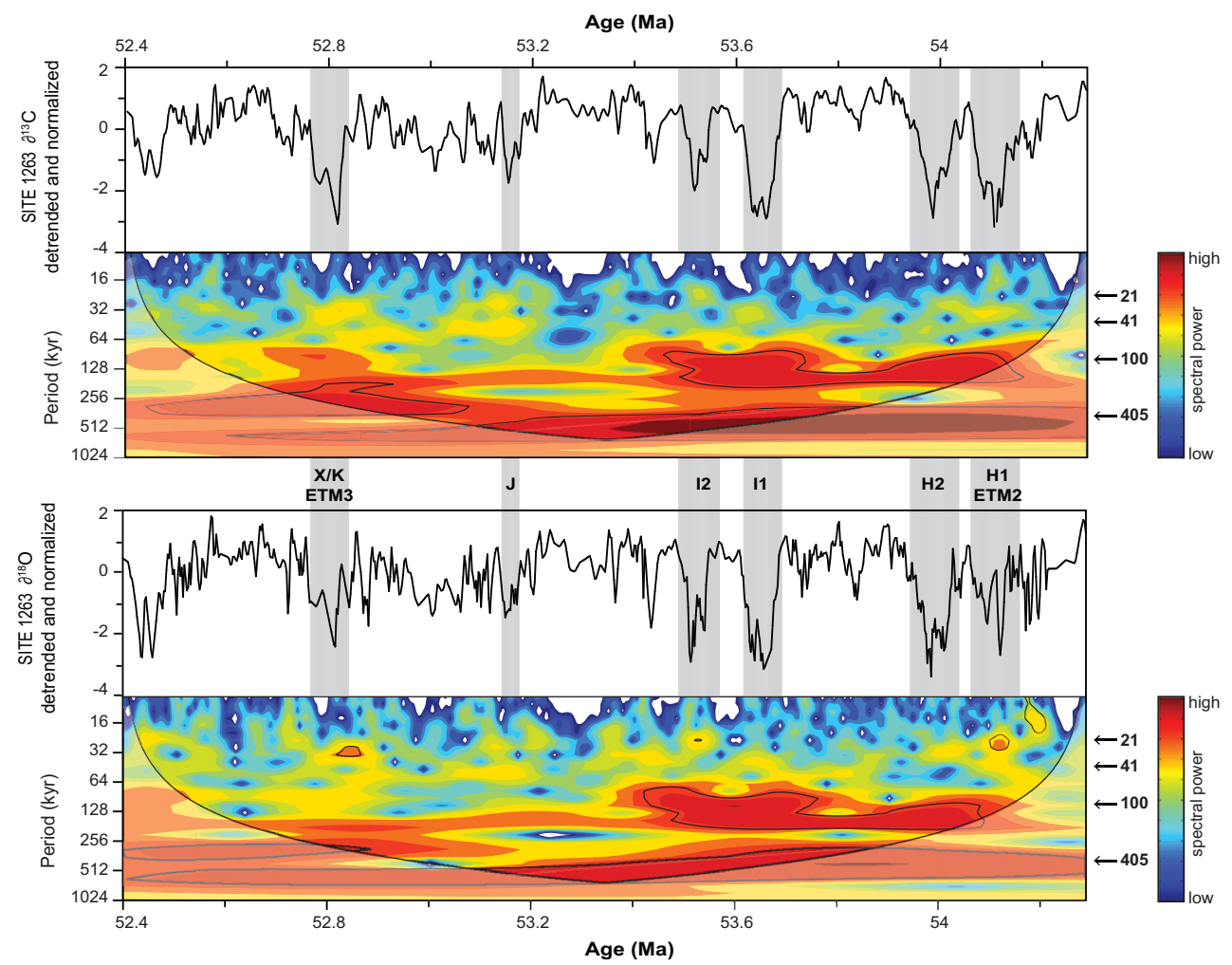

Figure 5. Evolutionary wavelet analyses for $\delta^{13} \mathrm{C}$ and $\delta^{18} \mathrm{O}$ were performed using a Morlet mother wavelet of an order of 6. Shaded areas represent $95 \%$ significance levels. Spectral power above the confidence level is concentrated at distinct frequencies, corresponding to the long (405 kyr) and short eccentricity ( $100 \mathrm{kyr})$ cycles. Highlighted intervals represent the position of the early Eocene hyperthermal events.

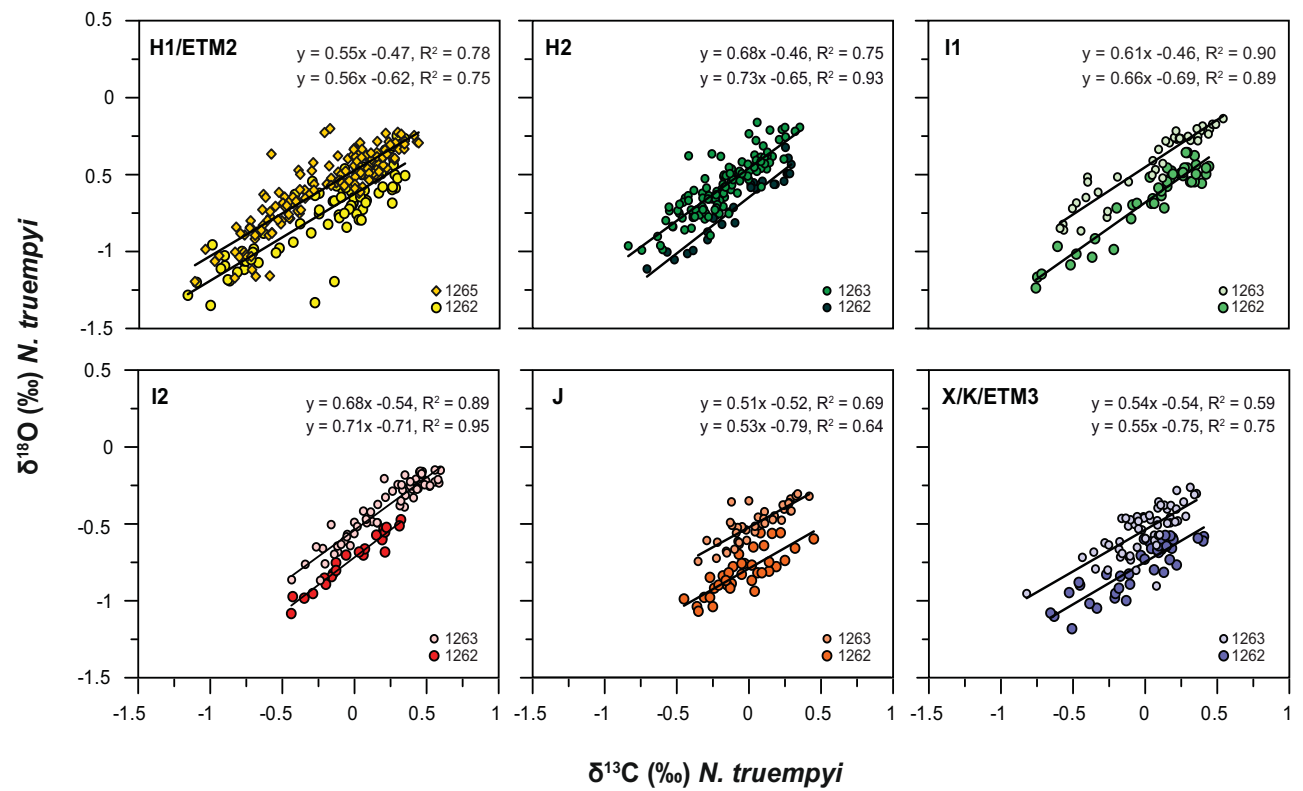

Figure 6. Relationship between the oxygen and carbon isotope values of $N$. truempyi during ETM2, H2, I1, I2, J and ETM3/X at Site 1263 and Site 1262. Note that, because of intense dissolution at Site 1263, ETM2 data were chosen from Site 1265 (Stap et al., 2010 ). For all the events, throughout the entire event (onset+recovery phases), changes in the exogenic carbon pool are linearly related to warming. Linear regression equations refer to Site 1263 (top) and Site 1262 (bottom), respectively. 

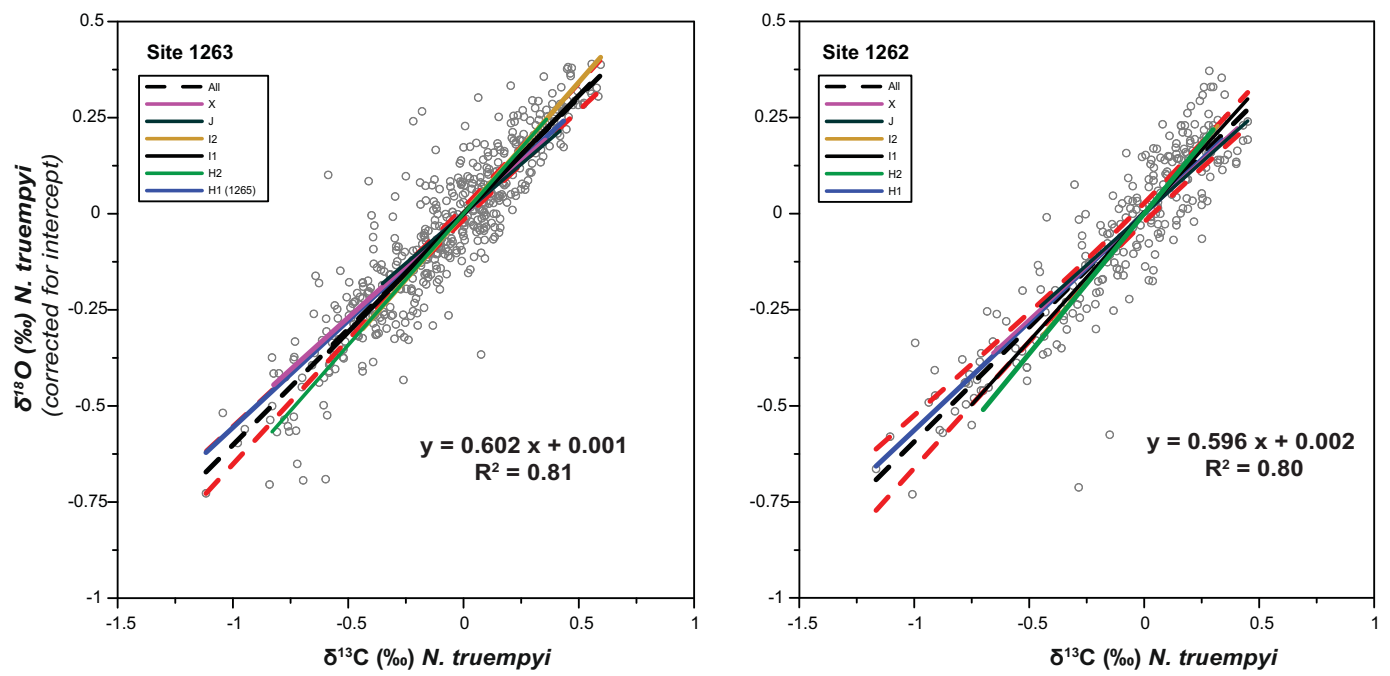

Figure 7. Regression line between $\delta^{13} \mathrm{C}$ and $\delta^{18} \mathrm{O}$ for each event plotted together with the average slope (from all the events) at each site. The red dashed line indicates the $99 \%$ confidence interval.

lated to the depletion and subsequent recharge time of the inferred methane clathrate reservoir between ETM2 and H2, and I1 and I2, could explain why the second event had both a smaller magnitude and possibly a smaller relative contribution of methanogenic carbon. The smaller magnitude of the two secondary carbon pulses, regardless of the isotopic composition of their source, seems feasible because the $a^{*}$ values, interpreted as representative of the degree of carbonate dissolution, were significantly lower than during their preceding counterparts (Fig. 2). In other words, the degree of carbonate dissolution associated with the shoaling of the calcite compensation depth (CCD) and lysocline appears to be less severe than during the first pulses. In this respect it is worth noting that $\mathrm{H} 2$ and $\mathrm{I} 2$ also behave differently from the "larger" events in terms of biotic disruption. During PETM, ETM2 and I1, rates of variability in planktonic communities indicate that the biotic response was proportional to the magnitude of carbon injections, and biotic disruption linearly declined along with the decreasing size of CIEs (Gibbs et al., 2012; Jennions et al., 2015). However, H2 and I2 do not show evidence of above-background variance, suggesting that during these events the system apparently failed to cross the environmental "threshold" necessary to generate a detectable marine biotic disruption (D'haenens et al., 2012; Gibbs et al., 2012). This all suggests that a change in the climate feedbacks and/or an incomplete recovery of the buffering capacity of the ocean system after the first perturbation could have played a significant role in amplifying the temperature response during the secondary pulse. On the other hand, we cannot dismiss the possibility that local circulation changes and/or partial dissolution slightly altered the anomalies in $\delta^{18} \mathrm{O}$ and $\delta^{13} \mathrm{C}$ during $\mathrm{H} 2$ and $\mathrm{I} 2$ at Walvis Ridge. Further research is hence needed to ratify the (global) significance of this finding.

\subsection{Thresholds and orbital pacing}

The transition towards the EECO is marked by a general decrease of both benthic carbon and oxygen isotopic values of $\sim 0.3 \%$ at Site 1263, indicative of both long-term warming and progressive oxidation of organic matter releasing $\mathrm{CO}_{2}$ into the ocean-atmosphere system. It has been theorized that the timing and magnitude of the hyperthermals would respond to the crossing of a thermal threshold, more frequently reached in phases of orbital-driven temperature increase (Lourens et al., 2005; Lunt et al., 2011). In addition, the carbon reservoir or capacitor (Dickens, 2003), regardless of its nature and as a result of the long-term temperature increase from the late Paleocene to the early Eocene, would be largely depleted by the peak of the EECO, leading to an interval free of hyperthermals. In turn, a series of orbitally paced global warming events of decreasing frequency and increased size are expected to occur during the post-EECO cooling phase when the carbon reservoir would have been progressively refilled (e.g., Kirtland Turner et al., 2014). This hypothesis has been questioned with data from a composite bulk stable isotope record of Site 1258 showing that a series of negative stable isotope excursions continued throughout the EECO. This evidence suggests that episodes of carbon release persisted during the peak of warmth and the onset of the cooling trend (Kirtland Turner et al., 2014). Kirtland Turner et al. (2014) suggest that the mechanisms operating in the early Eocene climate were not necessarily exceptional but actually similar to those invoked for the Oligocene and Miocene when cyclic variations in the carbon cycle were also clearly paced by orbital forcing, particularly in the eccentricity bands (Holbourn et al., 2007; Pälike et al., 2006; Zachos et al., 2001b). Although the carbon and oxygen isotope records of the Oligocene-Miocene and early 
Eocene are certainly paced by eccentricity, their appearance in terms of punctuation are clearly different. In particular, a relatively sudden release (storage) of large amounts of light carbon (e.g. methane hydrates) into the ocean-atmosphere system seems the only way to explain the unusual magnitude of the CIEs recorded at Walvis Ridge given the rate and/or magnitude of warming, as well as carbonate dissolution and changes in benthic assemblages associated with those events (Jennions et al., 2015; Stap et al., 2009).

\subsection{Site 1263 vs. Site 1262}

Comparison between the benthic $\delta^{13} \mathrm{C}$ and $\delta^{18} \mathrm{O}$ records of Sites 1263 and 1262 reveals an almost identical pattern, although $\delta^{18} \mathrm{O}$ values of Site 1263 are consistently $\sim 0.2 \%$ o heavier than those of Site 1262 (Figs. 3 and 4). A similar (reversed) pattern has been previously observed by Stap et al. (2009) in the case of ETM2, and attributed to differential dissolution from the shallowest to the deepest site. Conversely, selective dissolution seems unlikely to justify the persistent offset in $\delta^{18} \mathrm{O}$ values observed throughout the new post-ETM2 record presented herein. We posit that this offset may be linked to a different average isotopic composition of the water masses at those sites. Accordingly, the intermediate water masses reaching Site 1263 were more ${ }^{18} \mathrm{O}$ enriched than the deeper waters at Site 1262. The existence of a discrete intermediate water body in the early Eocene South Atlantic is supported by recent benthic foraminiferal assemblage, sedimentological evidence and Earth system modeling data across ETM2, which suggests that warming in the intermediate waters bathing Site 1263 led to differential patterns in sedimentary and ecological data between this site and the deeper Site 1262 (Jennions et al., 2015).

\section{Conclusions}

New high-resolution benthic stable isotope records from ODP Sites 1262 and 1263 provide a detailed framework to explore the (transient) nature of early Eocene hyperthermal events during the onset of the EECO. Our results further confirm the link between large-scale carbon release and climate response to orbital forcing, in particular to short- and long-eccentricity cycles. The transition towards the EECO is marked by a general decrease of both benthic carbon and oxygen isotopic values of $\sim 0.3 \%$ at Site 1263 , indicative of both long-term warming and progressive oxidation of organic matter releasing $\mathrm{CO}_{2}$ into the ocean-atmosphere system. Consistent covariance between benthic carbon and oxygen isotopes demonstrates that global temperatures and changes in the exogenic carbon pool were similarly coupled during each of the studied hyperthermal events. In this regard, we found that the second pulses of the paired hyperthermal events (i.e. $\mathrm{H} 2$ and I2) point to a slightly different behavior. Whether this implies a larger role for a carbon reservoir characterized by a heavier isotopic signature remains debat- able and, hence, allows for further consideration of other operational processes such as local circulation changes, partial dissolution, or different climate feedbacks. Finally we found a constant offset in oxygen isotopic values between Site 1263 and 1262, with the isotopic composition of the shallower waters at Site 1263 consistently heavier than at Site 1262, suggesting the presence of a discrete water body at intermediate depths of the Walvis Ridge transect.

Acknowledgements. We are grateful to Gerald Dickens, Lee Kump and Philip Sexton for their constructive comments. We thank the International Ocean Discovery Program (IODP) for providing the samples used in this study. We also thank A. van Dijk at Utrecht University, and Dyke Andreasen and Chih-Ting Hsieh at UCSC for analytical support. This research was funded by NWO-ALW grant (project no. 865.10.001) to L. J. Lourens. We thank F. Hilgen and H. A. Abels for providing valuable comments on the manuscript.

Edited by: G. Dickens

\section{References}

Abels, H. A., Clyde, W. C., Gingerich, P. D., Hilgen, F. J., Fricke, H. C., Bowen, G. J., and Lourens, L. J.: Terrestrial carbon isotope excursions and biotic change during Palaeogene hyperthermals, Nat. Geosci., 5, 326-329, doi:10.1038/ngeo1427, 2012.

Abels, H. A., Lauretano, V., van Yperen, A., Hopman, T., Zachos, J. C., Lourens, L. J., Gingerich, P. D., and Bowen, G. J.: Carbon isotope excursions in paleosol carbonate marking five early Eocene hyperthermals in the Bighorn Basin, Wyoming, Clim. Past Discuss., 11, 1857-1885, doi:10.5194/cpd-11-1857-2015, 2015.

Agnini, C., Macri, P., Backman, J., Brinkhuis, H., Fornaciari, E., Giusberti, L., Luciani, V., Rio, D., Sluijs, A., and Speranza, F.: An early Eocene carbon cycle perturbation at $\sim 52.5 \mathrm{Ma}$ in the Southern Alps: Chronology and biotic response, Paleoceanography, 24, PA2209, doi:10.1029/2008PA001649, 2009.

Bemis, B. E., Spero, H. J., Bijma, J., and Lea, D. W.: Reevaluation of the oxygen isotopic composition of planktonic foraminifera: Experimental results and revised paleotemperature equations, Paleoceanography, 13, 150-160, 1998.

Bijl, P. K., Schouten, S., Sluijs, A., Reichart, G.-J., Zachos, J. C., and Brinkhuis, H.: Early Palaeogene temperature evolution of the southwest Pacific Ocean, Nature, 461, 776-779, doi:10.1038/nature08399, 2009.

Cramer, B. S., Wright, J. D., Kent, D. V., and Aubry, M.-P.: Orbital climate forcing of $\delta^{13} \mathrm{C}$ excursions in the late Paleoceneearly Eocene (chrons C24n-C25n), Paleoceanography, 18, 1097, doi:10.1029/2003PA000909, 2003.

D'haenens, S., Bornemann, A., Stassen, P., and Speijer, R. P.: Multiple early Eocene benthic foraminiferal assemblage and $\delta^{13} \mathrm{C}$ fluctuations at DSDP Site 401 (Bay of Biscay - NE Atlantic), Mar. Micropaleontol., 88-89, 15-35, doi:10.1016/j.marmicro.2012.02.006, 2012.

DeConto, R. M., Galeotti, S., Pagani, M., Tracy, D., Schaefer, K., Zhang, T., Pollard, D., and Beerling, D. J.: Past extreme warming 
events linked to massive carbon release from thawing permafrost, Nature, 484, 87-91, doi:10.1038/nature10929, 2012.

Dickens, G. R.: Rethinking the global carbon cycle with a large, dynamic and microbially mediated gas hydrate capacitor, Earth Planet. Sci. Lett., 213, 169-183, doi:10.1016/S0012821X(03)00325-X, 2003.

Dickens, G. R, O’Neil, J. R., Rea, D. K., and Owen, R. M.: Dissociation of oceanic methane hydrate as a cause of the carbon isotope excursion at the end of the Paleocene, Paleoceanography, 10, 965-971, 1995.

Dinarès-Turell, J., Westerhold, T., Pujalte, V., Röhl, U., and Kroon, D.: Astronomical calibration of the Danian stage (Early Paleocene) revisited: Settling chronologies of sedimentary records across the Atlantic and Pacific Oceans, Earth Planet. Sci. Lett., 405, 119-131, doi:10.1016/j.eps1.2014.08.027, 2014.

Galeotti, S., Krishnan, S., Pagani, M., Lanci, L., Gaudio, A., Zachos, J. C., Monechi, S., Morelli, G., and Lourens, L. J.: Orbital chronology of Early Eocene hyperthermals from the Contessa Road section, central Italy, Earth Planet. Sci. Lett., 290, 192-200, doi:10.1016/j.eps1.2009.12.021, 2010.

Gibbs, S. J., Bown, P. R., Murphy, B. H., Sluijs, A., Edgar, K. M., Pälike, H., Bolton, C. T., and Zachos, J. C.: Scaled biotic disruption during early Eocene global warming events, Biogeosciences, 9, 4679-4688, doi:10.5194/bg-9-4679-2012, 2012.

Hilgen, F. J., Kuiper, K. F., and Lourens, L. J.: Evaluation of the astronomical time scale for the Paleocene and earliest Eocene, Earth Planet. Sci. Lett., 300, 139-151, doi:10.1016/j.eps1.2010.09.044, 2010.

Hilgen, F. J., Abels, H. A., Kuiper, K. F., Lourens, L. J., and Wolthers, M.: Towards a stable astronomical time scale for the Paleocene: Aligning Shatsky Rise with the Zumaia - Walvis Ridge ODP Site 1262 composite, Newsletters Stratigr., 48, 91110, doi:10.1127/nos/2014/0054, 2015.

Holbourn, A., Kuhnt, W., Schulz, M., Flores, J.-A., and Andersen, N.: Orbitally-paced climate evolution during the middle Miocene "Monterey" carbon isotope excursion, Earth Planet. Sci. Lett. 261, 534-550, 2007.

Hönisch, B., Ridgwell, A., Schmidt, D. N., Thomas, E., Gibbs, S. J., Sluijs, A., Zeebe, R., Kump, L., Martindale, R. C., Greene, S. E., Kiessling, W., Ries, J., Zachos, J. C., Royer, D. L., Barker, S., Marchitto, T. M., Moyer, R., Pelejero, C., Ziveri, P., Foster, G. L., and Williams, B.: The geological record of ocean acidification, Science, 335, 1058-63, doi:10.1126/science.1208277, 2012.

Hut, G.: Stable isotope reference samples for geochemical and hydrological investigations, Consultants Group Meeting, report, Int. At. Energy Agency,Vienna, Austria, 42 pp., 1987.

Jennions, S. M., Thomas, E., Schmidt, D. N., Lunt, D., and Ridgwell, A.: Changes in benthic ecosystems and ocean circulation in the Southeast Atlantic across Eocene Thermal Maximum 2, Paleoceanography, 30, doi:10.1002/2015PA002821, 2015.

Kennett, J. P. and Stott, L. D.: Abrupt deep-sea warming, palaeoceanographic changes and benthic extinctions at the end of the Palaeocene, Nature, 353, 225-229, doi:10.1038/353225a0, 1991.

Kirtland Turner, S., Sexton, P. F., Charles, C. D., and Norris, R. D.: Persistence of carbon release events through the peak of early Eocene global warmth, Nat. Geosci., 12, 1-17, doi:10.1038/ngeo2240, 2014
Kuiper, K. F., Deino, A., Hilgen, F. J., Krijgsman, W., Renne, P. R., and Wijbrans, J. R.: Synchronizing rock clocks of Earth history., Science, 320, 500-504, doi:10.1126/science.1154339, 2008.

Kurtz, A. C., Kump, L. R., Arthur, M. A., Zachos, J. C., and Paytan, A.: Early Cenozoic decoupling of the global carbon and sulfur cycles, Paleoceanography, 18, 1090, doi::10.1029/2003PA000908, 2003.

Laskar, J., Fienga, A., Gastineau, M., and Manche, H.: La2010: A new orbital solution for the long term motion of the Earth, Astron. Astrophys., 532, 15 pp., doi:10.1051/00046361/201116836, 2011.

Liebrand, D., Lourens, L. J., Hodell, D. A., de Boer, B., van de Wal, R. S. W., and Pälike, H.: Antarctic ice sheet and oceanographic response to eccentricity forcing during the early Miocene, Clim. Past, 7, 869-880, doi:10.5194/cp-7-869-2011, 2011.

Littler, K., Röhl, U., Westerhold, T., and Zachos, J. C.: A highresolution benthic stable-isotope record for the South Atlantic: Implications for orbital-scale changes in Late Paleocene-Early Eocene climate and carbon cycling, Earth Planet. Sci. Lett., 401, 18-30, doi:10.1016/j.eps1.2014.05.054, 2014.

Lourens, L. J., Sluijs, A., Kroon, D., Zachos, J. C., Thomas, E., Röhl, U., Bowles, J., and Raffi, I.: Astronomical pacing of late Palaeocene to early Eocene global warming events, Nature, 435, 1083-1087, doi:10.1038/nature03814, 2005.

Lunt, D. J., Valdes, P. J., Jones, T. D., Ridgwell, A., Haywood, A. M., Schmidt, D. N., Marsh, R., and Maslin, M.: $\mathrm{CO}_{2}$-driven ocean circulation changes as an amplifier of Paleocene-Eocene thermal maximum hydrate destabilization, Geology, 38, 875878, doi:10.1130/G31184.1, 2010.

Lunt, D. J., Ridgwell, A., Sluijs, A., Zachos, J. C., Hunter, S., and Haywood, A.: A model for orbital pacing of methane hydrate destabilization during the Palaeogene, Nat. Geosci., 4, 775-778, doi:10.1038/ngeo1266, 2011.

McInerney, F. A. and Wing, S. L.: The Paleocene-Eocene Thermal Maximum: A Perturbation of Carbon Cycle, Climate, and Biosphere with Implications for the Future, Annu. Rev. Earth Planet. Sci., 39, 489-516, doi:10.1146/annurev-earth-040610-133431, 2011.

Nicolo, M. J., Dickens, G. R., Hollis, C. J., and Zachos, J. C.: Multiple early Eocene hyperthermals: Their sedimentary expression on the New Zealand continental margin and in the deep sea, Geology, 35, 699, doi:10.1130/G23648A.1, 2007.

Paillard, D., Labeyrie, L., and Yiou, P.: Macintosh program performs time-series analysis, Eos Trans. AGU, 77, 379, 1996.

Pälike, H., Norris, R. D., Herrle, J. O., Wilson, P. A., Coxall, H. K., Lear, C. H., Shackleton, N. J., Tripati, A. K., and Wade, B. S.: The heart- beat of the Oligocene climate system, Science, 314, 1894-1998, 2006.

Renne, P. R., Deino, A. L., Hilgen, F. J., Kuiper, K. F., Mark, D. F., Mitchell, W. S., Morgan, L. E., Mundil, R., and Smit, J.: Time scales of critical events around the Cretaceous-Paleogene boundary, Science, 339, 684-687, doi::10.1126/science.1230492, 2013.

Röhl, U., Westerhold, T., Monechi, S., Thomas, E., Zachos, J. C., and Donner, B.: The Third and Final Early Eocene Thermal Maximum: Characteristics, Timing and Mechanisms of the ' $\mathrm{X}$ ' Event, GSA Annual Meeting 37, Geological Society of America, Salt Lake City, USA, 264 pp., 2005. 
Sexton, P. F., Norris, R. D., Wilson, P. A., Pälike, H., Westerhold, T., Röhl, U., Bolton, C. T., and Gibbs, S.: Eocene global warming events driven by ventilation of oceanic dissolved organic carbon, Nature, 471, 349-352, doi:10.1038/nature09826, 2011.

Shackleton, N. J. and Hall, M. A: The late Miocene stable isotope record, Site 926, Proc. Ocean Drill. Program Sci. Results, 154, 367-373, doi:10.2973/odp.proc.sr.154.119.1997, 1997.

Shackleton, N. J., Hall, M. A., and Boersma, A.: Oxygen and carbon isotope data from Leg-74 foraminifers, Initial Rep. Deep Sea Drill. Project, 74, 599-612, 1984.

Slotnick, B. S., Dickens, G. R., Nicolo, M. J., Hollis, C. J., Crampton, J. S., Zachos, J. C., and Sluijs, A.: LargeAmplitude Variations in Carbon Cycling and Terrestrial Weathering during the Latest Paleocene and Earliest Eocene: The Record at Mead Stream, New Zealand, J. Geol., 120, 487-505, doi:10.1086/666743, 2012.

Sluijs, A., Brinkhuis, H., Schouten, S., Bohaty, S. M., John, C. M., Zachos, J. C., Reichart, G.-J., Sinninghe Damsté, J. S., Crouch, E. M., and Dickens, G. R.: Environmental precursors to rapid light carbon injection at the Palaeocene/Eocene boundary, Nature, 450, 1218-1221, doi:10.1038/nature06400, 2007.

Stap, L., Sluijs, A., Thomas, E., and Lourens, L. J.: Patterns and magnitude of deep sea carbonate dissolution during Eocene Thermal Maximum 2 and H2, Walvis Ridge, southeastern Atlantic Ocean, Paleoceanography, 24, PA1211, doi:10.1029/2008PA001655, 2009.

Stap, L., Lourens, L. J., Thomas, E., Sluijs, A., Bohaty, S., and Zachos, J. C.: High-resolution deep-sea carbon and oxygen isotope records of Eocene Thermal Maximum 2 and H2, Geology, 38, 607-610, doi:10.1130/G30777.1, 2010.

Thomas, E. and Shackleton, N. J.: The Paleocene-Eocene benthic foraminiferal extinction and stable isotope anomalies, Geol. Soc. London, Spec. Publ., 101, 401-441, doi::10.1144/GSL.SP.1996.101.01.20, 1996.

Westerhold, T. and Röhl, U.: High resolution cyclostratigraphy of the early Eocene - new insights into the origin of the Cenozoic cooling trend, Clim. Past, 5, 309-327, doi:10.5194/cp-5309-2009, 2009.
Westerhold, T., Röhl, U., Laskar, J., Raffi, I., Bowles, J., Lourens, L. J., and Zachos, J. C.: On the duration of magnetochrons $\mathrm{C} 24 \mathrm{r}$ and $\mathrm{C} 25 \mathrm{n}$ and the timing of early Eocene global warming events: Implications from the Ocean Drilling Program Leg 208 Walvis Ridge depth transect, Paleoceanography, 22, PA2201, doi:10.1029/2006PA001322, 2007.

Westerhold, T., Röhl, U., Raffi, I., Fornaciari, E., Monechi, S., Reale, V., Bowles, J., and Evans, H. F.: Astronomical calibration of the Paleocene time, Palaeogeogr. Palaeoclimatol. Palaeoecol., 257, 377-403, doi:10.1016/j.palaeo.2007.09.016, 2008.

Zachos, J. C., Pagani, M., Sloan, L., Thomas, E., and Billups, K.: Trends, rhythms, and aberrations in global climate $65 \mathrm{Ma}$ to present, Science, 292, 686-693, 2001a.

Zachos, J. C., Shackleton, N. J., Revenaugh, J. S., Pälike, H., and Flower, B. P., Periodic and non-periodic climate response to orbital forcing across the Oligocene-Miocene boundary, Science, 292, 274-277, 2001b.

Zachos, J. C., Kroon, D., and Blum, P.: ODP Leg 208: The early Cenozoic extreme climates transect along Walvis Ridge, Proceedings of the Ocean Drilling Program Initial Reports, 208 pp., 2004.

Zachos, J. C., Röhl, U., Schellenberg, S. A., Sluijs, A., Hodell, D. A., Kelly, D. C., Thomas, E., Nicolo, M., Raffi, I., Lourens, L. J., McCarren, H., and Kroon, D.: Rapid acidification of the ocean during the Paleocene-Eocene thermal maximum, Science, 308, 1611-1615, doi:10.1126/science.1109004, 2005.

Zachos, J. C., Dickens, G. R., and Zeebe, R. E.: An early Cenozoic perspective on greenhouse warming and carbon-cycle dynamics, Nature, 451, 279-283, doi:10.1038/nature06588, 2008.

Zachos, J. C., McCarren, H., Murphy, B., Röhl, U. and Westerhold, T.: Tempo and scale of late Paleocene and early Eocene carbon isotope cycles: Implications for the origin of hyperthermals, Earth Planet. Sci. Lett., 299, 242-249, doi:10.1016/j.epsl.2010.09.004, 2010.

Zeebe, R. E. and Zachos, J. C.: Long-term legacy of massive carbon input to the Earth system: Anthropocene versus Eocene, Philos. Trans. A. Math. Phys. Eng. Sci., 371, 20120006, doi:10.1098/rsta.2012.0006, 2013. 